\title{
Quantitative assessment of Lactococcus lactis subsp. cremoris present in artisanal raw cow's milk cheese
}

\author{
Milena Alicja Stachelska \\ Lomza State University of Applied Sciences, Institute of Food Technology and Gastronomy, \\ Łomża, Poland \\ Received November 5, 2017 \\ Accepted May 15, 2018
}

\begin{abstract}
Lactococcus lactis subsp. cremoris belongs to lactic acid bacteria that play a crucial role in cheese production and it is known to be beneficial to human health. The aim of the study was to establish a rapid and accurate quantitative real-time polymerase chain reaction (qPCR) method to detect and enumerate L. lactis subsp. cremoris in artisanal raw cow's milk cheese. Artisanal raw cow's milk cheese samples were used to check for presence and number of L. lactis subsp. cremoris strains. The method applies a set of target-specific PCR (polymerase chain reaction) primers and a fluorogenic probe, and amplifies a part of the LACR_RS01280 gene that encodes the aminoacetone oxidase family flavin adenine dinucleotide (FAD) binding enzyme. All 5 L. lactis subsp. cremoris strains examined were found to be qPCR positive. There was no signal recorded for 8 strains which belong to closely related species. The limit of detection amounted to ten copies per reaction and the assay indicated a linear dynamic range of seven logs. This method may be applied in detection and enumeration of L. lactis subsp. cremoris in cheese during its ripening. Moreover, it may be applied to examine the distribution of L. lactis subsp. cremoris during the cheese production and ripening.
\end{abstract}

Lactic acid bacteria, quantitative PCR, cheese ripening, aminoacetone oxidase family FAD-binding enzyme gene

Lactococcus lactis subsp. cremoris belongs to lactic acid bacteria (LAB) and is responsible for the transformation of lactose and other carbohydrates mainly into lactic acid. Lactic acid bacteria are present in different matrixes which are rich in nutritional compounds. They can be found in soil, fermented food, the body surface and in the intestinal tract of humans and animals (Wouters et al. 2002). Strains of L. lactis subsp. cremoris find their application in the manufacturing and ripening of hard cheeses. Lactococcus lactis subsp. cremoris is responsible for the proper acidification of milk during cheese manufacturing. The growth of this microorganism in milk is strongly related with the intense production of lactic acid, which leads to curd formation, and inhibits the growth of pathogenic and spoilage bacteria (Irlinger and Mounier 2009). Lactococcus lactis subsp. cremoris attracts attention of many authors who investigate its functional and metabolic gene expression (Corpet 1988). It improves the flavour and texture of many hard, soft, ultra-filtered and low-fat cheese types. The ability of L. lactis subsp. cremoris to survive during cheese ripening and its ability to transform proteins into peptides and amino acids prove its possible technological role in flavour formation. It produces cell-envelope bound proteases and intracellular peptidases which are responsible for protein degradation during cheese ripening (Falentin et al. 2010; Falentin et al. 2012).

Due to its beneficial traits, L. lactis subsp. cremoris should be carefully detected and enumerated in cheeses. Developing a simple, fast and reliable method for quantification of L. lactis subsp. cremoris makes it possible to examine its number in milk production

Address for correspondence:

Milena Alicja Stachelska

Institute of Food Technology and Gastronomy

Lomza State University of Applied Sciences

Phone: +48798385983

Akademicka 14, 18-400 Łomża, Poland 
and fermentation during the production of artisanal cheese (Friedrich and Lenke 2006). This cheese is produced by traditional techniques using unpasteurised milk and without adding any commercial starters which are deliberately added when cheese is produced from pasteurised milk. This particular cheese is produced in the Podlaskie regions of north-eastern Poland, ripening at $15{ }^{\circ} \mathrm{C}$ for 3 days then at $4{ }^{\circ} \mathrm{C}$ for 3 weeks. Original microflora present in raw milk is responsible for the ripening of this cheese as no starters are added (Beresford et al. 2001). All the phases of manufacturing are carried out manually. This distinctive cheese is closely connected with the territory of production and its tradition which are unique by their historical and cultural environment.

The aim of the study was to acquire more knowledge of the microbiology of this artisanal cheese produced from unpasteurised milk and its impact on cheese ripening and flavour formation. Preliminary microbiological examinations have proved that L. lactis subsp. cremoris constitutes one of the dominant species present (data not shown). A speciesspecific, fast and reliable method enabling the detection and enumeration of $L$. lactis subsp. cremoris constitutes a precious tool to examine the distributions of representatives of this species in the cheese ripening process. In this study, we developed a set of target-specific PCR (polymerase chain reaction) primers and a fluorogenic probe which amplifies a part of the LACR RS01280 gene that encodes the aminoacetone oxidase family FAD (flavin adenine dinucleotide)-binding enzyme. Such method enables to detect and enumerate L. lactis subsp. cremoris in cheeses. This method occurred to be specific for L. lactis subsp. cremoris and was applied to quantify this species in cheese.

Table 1 . The specificity and sensitivity test using 13 strains for checking the specificity of the quantitative polymerase chain reaction (qPCR) assay.

\begin{tabular}{|c|c|}
\hline Strain & $\mathrm{qPCR}$ result \\
\hline Lactococcus lactis subsp. cremoris A76 & + \\
\hline Lactococcus lactis subsp. cremoris MG1363 & + \\
\hline Lactococcus lactis subsp. cremoris NZ9000 & + \\
\hline Lactococcus lactis subsp. cremoris ATCC ${ }^{\circledR} 19257$ & + \\
\hline Lactococcus lactis subsp. cremoris SK11 & + \\
\hline Lactococcus lactis subsp. lactis CV56 & - \\
\hline Lactococcus lactis subsp. lactis ATCC ${ }^{\circledR} 11454^{\mathrm{TM}}$ & - \\
\hline Lactococcus lactis subsp. lactis ATCC ${ }^{\circledR} 19435^{\mathrm{TM}}$ & - \\
\hline Lactococcus lactis subsp. lactis I11403 & - \\
\hline Lactococcus lactis subsp. lactis KF147 & - \\
\hline Lactococcus garvieae 21881 & - \\
\hline Lactococcus garvieae ATCC 49156 & - \\
\hline Lactococcus garvieae Lg2 & - \\
\hline
\end{tabular}

buffer DLF (desbutyllumefantrine) was added. The tube was closed and mixed by vortexing. The total volume of supernatant could not be less than $700 \mu$ l. Then, $30 \mu \mathrm{l}$ of proteinase $\mathrm{K}$ was added, the tube was closed and mixed by vortexing, and then incubated at $60^{\circ} \mathrm{C}$ for $30 \mathrm{~min}$. During the incubation, the sample was vortexed twice. The sample was incubated for $5 \mathrm{~min}$ on ice. Then it was centrifuged for $5 \mathrm{~min}$ at $2,500 \times \mathrm{g}$. Then, $700 \mu 1$ of the supernatant was transferred to a new $2 \mathrm{ml}$ tube. In some food samples, three phases can be formed. In this case, $700 \mu 1$ of the middle phase was transferred to a new $2 \mathrm{ml}$ tube. Then $500 \mu \mathrm{l}$ of chloroform was added, the tube was closed and vortexed for $15 \mathrm{~s}$. Then the tube was centrifuged for $15 \mathrm{~min}$ at $14,000 \times \mathrm{g}$. Then $350 \mu \mathrm{l}$ of the upper phase was transferred to a new $2 \mathrm{ml}$ tube, then $350 \mu \mathrm{l}$ of buffer desbutylwumefantrine (DWF) was added. The lid was closed, the tube was vortexed for $10 \mathrm{~s}$ then centrifuged for $20 \mathrm{~s}$ at $18,000 \times \mathrm{g}$. The DF column (degrees of freedom) was placed in a $2 \mathrm{ml}$ tube. All the material was transferred into the DF column. The lid was closed. The tube was centrifuged for $30 \mathrm{~s}$ at $11,000 \times \mathrm{g}$. The supernatant was discarded, and the column was transferred back to the tube. Then 
$700 \mu 1$ of buffer DPF (phosphate buffer) was added to the column, then the lid of the column was closed. The column was centrifuged for $30 \mathrm{~s}$ at $18,000 \times g$. The supernatant was discarded, and the column was transferred back to the tube. The column was centrifuged for $3 \mathrm{~min}$ at $18,000 \times \mathrm{g}$. The column was transferred to a new $1.5 \mathrm{ml}$ tube. Then 100-200 $\mu$ l of pre-warmed DE elution buffer were added to the centre of the membrane and incubated at room temperature for $1 \mathrm{~min}$. The lid was closed and the tube was centrifuged for $1 \mathrm{~min}$ at maximum speed $(18,000 \times g)$. The final volume of the eluted DNA was $100 \mu l$.

\section{Oligonucleotide primer and probe design}

The sequence of the gene was provided by GenBank (www.ncbi.nlm.nih.gov/Genbank/; Accession Number NC_008527.1). The nucleotide sequences of the LACR_RS01280 gene that encodes the aminoacetone oxidase family FAD-binding enzyme which are unique to L. lactis subsp. cremoris were compared with those of closely related strains. The primer/probe set was designed using Primer Express Software v3.0 (Applied Biosystems, Foster City, CA, USA). The set was validated using NCBI (National Center for Biotechnology Information) BLAST (Basic Local Alignment Search Tool: www.ncbi.nlm.nih.gov/blast/). Thereby, a 77-bp region from nucleotide position 243826 to 243903 within the LACR_RS01280 gene was found to be a potential target site because it was identical in all of the examined L. lactis subsp. cremoris strains but indicated variability in other LAB species. The sequences were as follows: forward primer 5'-CGGTTGAACCTGTGGAAGG-3'; reverse primer 5'-CTGATAGTGAAAGCTATTTAAGTCCA-3'; probe 5'-FAM- AATCGTTCTCTCTACGGGTGGTCGTGCCTA -3'-MGB-NFQ. The oligonucleotides were synthesised and purchased from Eurofins Genomics (Ebersberg, Germany).

PCR fragments solutions of LACR_RS01280 gene, standard curves of molecular quantification

The LACR RS01280 gene fragments of L. lactis subsp. cremoris were synthesised and purchased from Eurofins Genomics (Ebersberg, Germany). The sequence of the gene was provided by GenBank (www.ncbi. nlm.nih.gov/Genbank/; Accession Number NC_008527.1, region from 243086 to 244360). They were delivered in the lyophilized form. Standard curves were prepared with serial dilutions of genomic DNA isolated from L. lactis subsp. cremoris. There were $1.27 \times 10^{12} \mathrm{DNA}$ copies in a delivered tube. They were dissolved in $1,270 \mu 1$ of DE buffer (Syngen Biotech, Wrocław, Poland) achieving the concentration of $1 \times 10^{9}$ DNA copies $/ \mu 1$ of eluate. This concentration was used for preparation of standards for standard curve. The dilutions were prepared to achieve $10^{1}$ DNA copies $/ \mu$ l of eluate at the highest dilution. A 10 -fold dilution series of the PCR fragment solution for each bacterial species, covering 7 logs ranging from $10^{1}$ to $10^{7}$ DNA copies per reaction, were used to estimate the sensitivity of the method.

\section{Real-time PCR conditions}

The reaction total volume was $20 \mu$ l. Real-time PCR analysis was performed using Stratagene Mx3005P thermocycler (Agilent Technologies, Santa Clara, CA, USA). The PCR mixture contained $5 \mu$ l DNA template, $4 \mu \mathrm{l}$ of Quantum Probe Mix (Syngen Biotech, Cambridge, United Kingdom), $0.8 \mu \mathrm{l}$ of primers F and R each, $0.5 \mu 1$ of the hydrolysis probe, and $8.9 \mu 1$ of PCR water. A non-template control (NTC) contained $5 \mu 1$ of water instead of DNA and was included in each run. The real-time PCR cycling parameters were the following: 1 cycle of amplification $\left(95{ }^{\circ} \mathrm{C}\right.$ for $\left.5 \mathrm{~min}\right)$ and 35 cycles of amplification $\left(94{ }^{\circ} \mathrm{C}\right.$ for $30 \mathrm{~s}, 60{ }^{\circ} \mathrm{C}$ for $30 \mathrm{~s}$, $72{ }^{\circ} \mathrm{C}$ for $90 \mathrm{~s}$ ). The fluorescence of the reporter dye (FAM) was measured during amplification at $510 \mathrm{~nm}$. The real-time PCR reaction and amplification step were carried out using a DNA amplification curves which were the subject of the analysis. The calculation of the threshold cycle $\left(C_{T}\right)$ value was carried out using Stratagene Mx3005P software version 2.1 (Agilent Technologies, Santa Clara, CA, USA). The $C_{T}$ value was described as the real-time PCR cycle, at which the generated fluorescence increased exponentially and exceeded its background level. The standard curve was created by plotting the threshold cycle $\left(C_{T}\right)$ values as a function of the concentration of recombinant LACR_RS01280 standard gene copies per $\mu$ l. All standard and sample reactions were run in triplicate.

\section{qPCR specificity, sensitivity, and efficiency}

At the beginning, the specificity of the primer/probe design was assessed by the NCBI Primer-BLAST tool. Then, the specificity of the primer/probe set was examined experimentally with gDNA (genomic deoxyribonucleic acid) which was isolated from different bacterial strains (Table 1). The sensitivity of the qPCR assay was examined by preparing a serial tenfold dilution of the plasmid LACR_RS01280 which was treated as a positive control. The dilutions were examined by qPCR and the number of DNA copies contained in each dilution was used to calculate the limit of detection (LOD) and the linearity of the qPCR assay. The standard curve was created by plotting the $\mathrm{Ct}$ values of all dilutions as a function of the concentration of DNA copies and calculating the linear regression in $\mathrm{R}^{2}$. qPCR efficiency was assessed using standard curves with an equation PCR efficiency of $\left(10^{-1 / 1 \text { lope }}\right)-1$.

The efficiency of the sum of DNA extraction plus qPCR was assessed by comparing the calculated copy numbers with the colony forming units per $\mathrm{ml}(\mathrm{cfu} / \mathrm{ml})$. In order to realize it, a culture of $L$. lactis subsp. cremoris 
SK11 containing $8.82 \times 10^{8}$ per $\mathrm{ml}$ was serially diluted tenfold in raw milk. Two dilution series were prepared and DNA coming from each dilution sample was extracted as described above before giving it to qPCR. The concentration of $\mathrm{cfu} / \mathrm{ml}$ in the M17 broth was assessed by plate counting using M17 agar, pH 7.1 (Oxoid, Basingstoke, UK) at $30^{\circ} \mathrm{C}$ for $48 \mathrm{~h}$.

Statistical analysis

Each experiment was repeated at least three times and data were analysed using analysis of variance (ANOVA) and Duncan multiple range test $(P<0.05)$.

\section{Results}

Specificity of the LACR_RS01280 targeted primers and probe

The analysis carried out by the PrimerProbe-BLAST tool against the RefSeq database indicated that the set of probe and primers aligned with $100 \%$ identity to the LACR_RS01280 gene of L. lactis subsp. cremoris only (data not presented). To check the specificity of the probe/primers set, qPCR experiments were carried out using gDNA extracted from 5 L. lactis subsp. cremoris strains and 8 closely related strains belonging to other LAB species. The target region was the subject of amplification in all L. lactis subsp. cremoris strains. There was no signal detected in the rest of the 8 strains belonging to the other LAB species examined (Table 1).

Copy number of the aminoacetone oxidase family FAD-binding enzyme gene in L. lactis subsp. cremoris genomes

L. lactis subsp. cremoris genomes available in the GenBank database were searched for the the aminoacetone oxidase family FAD-binding enzyme gene. All genomes were found to possess a single copy of the gene.

Sensitivity and linearity of the aminoacetone oxidase family FAD-binding enzyme gene specific qPCR

Both the sensitivity and efficiency of the qPCR assay were assessed with a plasmid which contains a 240-bp region of the aminoacetone oxidase family FAD-binding enzyme gene and by preparing a dilution series of L. lactis subsp. cremoris SK11 in raw milk. The plasmid was restricted to obtain a linearised form. Seven dilution series of the linear plasmid showed a linear relationship from 10 to $10^{7}$ copies/ $\mu$ l (Fig. 1). The equation of the linear regression amounted to $\mathrm{Cq}=-3.429 \times+37.32$ with a correlation coefficient $\left(\mathrm{R}^{2}\right)$ of 1.000 . The efficiency amounted to $95.7 \%$. In the case when there were less than 10 copies in dilution, no signal was achieved in all triplicate measurements. It means that the limit of detection was 10 copies/ $\mu 1$.

Application of the newly designed qPCR assay

At the beginning, the possibility of applying the qPCR assay was tested with artisanal raw cow's milk cheese. The cheese was produced without a L. lactis subsp. cremoris adjunct culture. Lactobacillus lactis subsp. cremoris was detected in the cheese which indicated that it was present in raw cow's milk used for the production of the cheese. The population level of $L$. lactis subsp. cremoris, represented by the copy number, amounted to $6.28 \times 10^{7}$ copies per gram of cheese after $24 \mathrm{~h}$ of ripening, dropping to $3.85 \times 10^{6}$ copies per gram of cheese after 7 days and $2.43 \times 10^{6}$ copies per gram of 14 days of ripening (Table 2 ).

\section{Discussion}

The qPCR method is known to be a valuable alternative to culture methods of enumerating bacteria. The DNA-based methods are considered to be specific, sensitive 


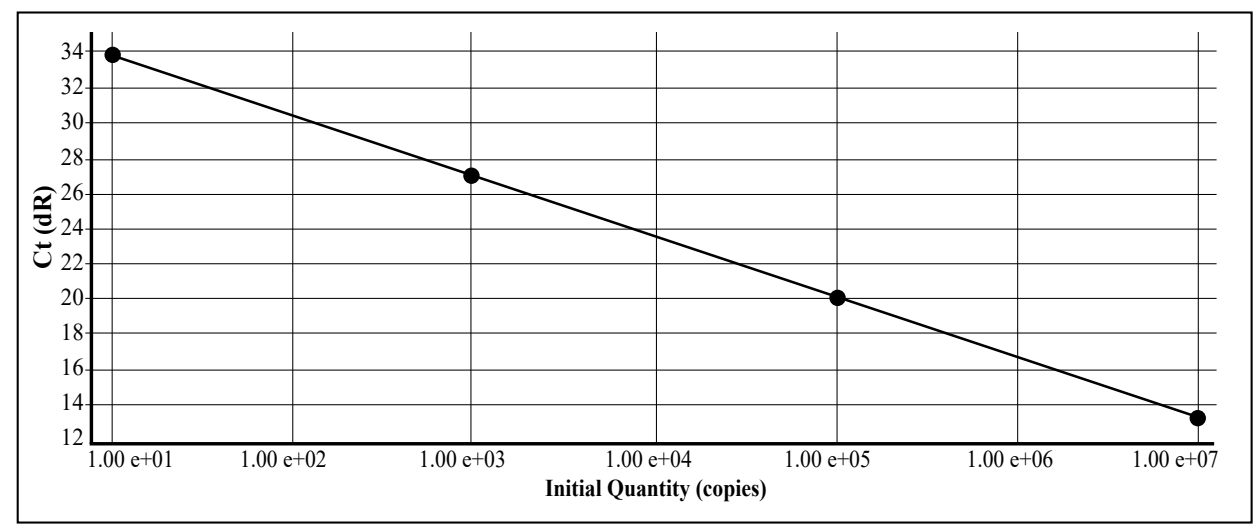

Fig. 1. Plasmid standard curve obtained by plotting the threshold cycle $(\mathrm{Ct})$ values against the calculated gene copy numbers from serial tenfold dilutions of plasmid in which the aminoacetone oxidase family FAD (flavin adenine dinucleotide)-binding enzyme gene is inserted.

Table 2. The mean number of L. lactis subsp. cremoris cells in the samples of raw cow's milk cheese achieved using the qPCR.

\begin{tabular}{lc}
\hline Period of ripening & $\begin{array}{c}\text { Number of aminoacetone oxidase } \\
\text { family FAD-binding enzyme } \\
\text { gene copies per } 1 \text { gram of cheese } \\
\text { using the qPCR method }\end{array}$ \\
\hline After 24-h production & $6.28 \times 10^{7}$ copies $/ g$ \\
After 7-day ripening & $3.85 \times 10^{6}$ copies $/ g$ \\
After 14-day ripening & $2.43 \times 10^{6}$ copies/g \\
\hline
\end{tabular}

qPCR - quantitative real-time polymerase chain reaction; FAD - flavin adenine dinucleotide chosen to target a region of the aminoacetone oxidase family FAD-binding enzyme gene, which is known to be an appropriate target gene for the specific identification of LAB species (Grattepanche et al. 2005; Nd oye et al. 2011). We examined our qPCR assay with 13 strains that belong to LAB species (Table 1). The designed assay was specific and sensitive to L. lactis subsp. cremoris and did not detect the closely related L. lactis subsp. lactis and L. garvieae. In our study the plasmid standard was used for absolute quantification. We used linearised plasmids in our qPCR assays as in the case of circular plasmid standards there is a risk of a major overestimation of the expected concentration. The qPCR enabled to achieve linear quantification over the range of 7 logs, with a limit of detection of ten copies per reaction (Fig. 1). The whole genome of L. lactis subsp. cremoris was searched and it was found that the aminoacetone oxidase family FAD-binding enzyme gene is a single copy gene, which means that ten bacterial cells can be detected.

The method characterised in this study is more reliable compared to the culture methods as we determined approximately one additional log of copies of the aminoacetone oxidase family FAD-binding enzyme gene (Carraro et al. 2011). We assume that such difference can be explained by the fact that there may have been created cell chains which were not separated during plating. Furthermore, microscopic examination proved that the L. lactis subsp. cremoris strains used in this study are able to form cell chains (data not shown). 
Table 3. Dairy samples used for detection and quantification of $L$. lactis subsp. cremoris by the qPCR (quantitative real-time polymerase chain reaction) $)^{\mathrm{a}}$.

\begin{tabular}{lc}
\hline Sample & $\begin{array}{c}\text { log aminoacetone oxidase } \\
\text { family FAD-binding enzyme } \\
\text { gene copies per gram or } \mathrm{ml}\end{array}$ \\
\hline Goat cheese, Switzerland & $6.18+/-0.03$ \\
Grana Padano PDO, Italy & $7.23+/-0.05$ \\
Provolone, Italy & $6.87+/-0.11$ \\
Parmigiano Reggiano PDO, Italy & $8.45+/-0.08$ \\
Gruyere PDO, Switzerland & $7.96+/-0.07$ \\
Raw cheesemaking milk & $3.02+/-0.12$ \\
Raw cheesemaking milk & $2.98+/-0.08$
\end{tabular}

${ }^{a}$ Mean values for triplicate measurements (+/- standard deviation) are presented; PDO - Protected Designation of Origin.

per gram what proved that L. lactis subsp. cremoris belongs to the most common species present in the natural starter cultures used for the production of Grana Padano and Parmigiano Reggiano (Charlet et al. 2009). It should be noted that the production parameters for Gruyere PDO (Protected Designation of Origin) are different from the parameters of Italian cooked, extra-hard cheeses. Thus, there is a strong need to study the microbial composition of these cheeses (Sohier et al. 2012). Lactobacillus lactis subsp. cremoris was detected at a low population in raw milk used for the production of the artisanal raw cow's milk cheese proving that raw milk is also the ecosystem for L. lactis subsp. cremoris strains.

Lactobacillus lactis subsp. cremoris was detected and enumerated in the artisanal raw cow's milk cheese and other cheese types. The presence of intracellular high-molecularweight compounds in the form of DNA, RNA, and bacterial enzymes can be considered an indicator of bacterial autolysis, which is strongly connected with the increased protein degradation during cheese ripening. Unless completely degraded, the DNA may be a species-specific and sensitive indicator of the autolysis process in a mixed population (Furet et al. 2004; Hanna et al. 2005). Lactobacillus lactis subsp. cremoris was able to grow in numbers of more than $10^{7}$ copies per gram of cheese after $24 \mathrm{~h}$. However, more than $10^{6}$ free aminoacetone oxidase family FAD-binding enzyme gene copies per gram were detected after 7 and 14 days of ripening, suggesting that the DNA was leaking out of the cells into the cheese matrix.

The qPCR assay designed to detect and quantify L. lactis subsp. cremoris occurred to be very specific and sensitive. It was possible to distinguish $L$. lactis subsp. cremoris from its closest relatives. Achievement of such high specificity and sensitivity makes this qPCR assay a useful tool for the detection and quantification of L. lactis subsp. cremoris in dairy products. The assay might find its application in the fast and reliable identification of colonies on agar plates; in examining the spatial and temporal distributions of L. lactis subsp. cremoris during cheese ripening; in investigating the habitats of L. lactis subsp. cremoris in the process of milk production and transformation. In conclusion, the qPCR assay characterised in this study is a useful tool for a variety of applications in research and industry.

\section{Acknowledgements}

The research was supported by the funds granted by Ministry of Science and Higher Education within Project No PBw.441.11.15. 


\section{Conflict of Interest}

The author declares no potential conflict of interest.

\section{References}

Beresford TP, Fitzsimons NA, Brennan NL, Cogan TM 2001: Recent advances in cheese microbiology. Int Dairy J 11: $259-274$

Carraro L, Maifreni M, Bartolomeoli I, Martino ME, Novelli E, Frigo F, Marino M, Cardazzo B 2011: Comparison of culture-dependent and -independent methods for bacterial community monitoring during Montasio cheese manufacturing. Res in Microbiol 162: 231-239

Charlet M, Duboz G, Faurie F, Le Quéré JL, Berthier F 2009: Multiple interactions between Streptococcus thermophilus, Lactobacillus helvetius and Lactobacillus delbrueckii strongly affect their growth kinetics during the making of hard cooked cheeses. Int J Food Microbiol 131: 10-19

Corpet F 1988: Multiple sequence alignment with hierarchical clustering. Nucleic Acids Res 16: 10881-10890

Falentin H, Henaff N, Le Bivic P, Deutsch SM, Parayre S, Richoux R, Sohier D, Thierry A, Lortal S, Postollec F 2012: Reverse transcription quantitative PCR revealed persistency of thermophilic lactic acid bacteria metabolic activity until the end of the ripening of Emmental cheese. Food Microbiol 29: 132-140

Falentin H, Postollec F, Parayre S, Henaff N, Le Bivic P, Richoux R, Thierry A, Sohier D 2010: Specific metabolic activity of ripening bacteria quantified by real-time reverse transcription PCR throughout Emmental cheese manufacture. Int J Food Microbiol 144: 10-19

Friedrich U, Lenke J 2006: Improved enumeration of lactic acid bacteria in mesophilic dairy starter cultures by using multiplex quantitative real-time PCR and flow cytometry fluorescence in situ hybridization. Appl Environ Microb 72: 4163-4171

Furet JP, Quénée P, Tailliez P 2004: Molecular quantification of lactic acid bacteria in fermented milk products using real-time quantitative PCR. Int J Food Microbiol 97: 197-207

Ganesan B, Stuart MR, Weimer BC 2007: Carbohydrate starvation causes a metabolically active but nonculturable state in Lactococcus lactis. Appl Environ Microb 73: 2498-2512

Grattepanche F, Lacroix C, Audet P, Lapointe G 2005: Quantification by real-time PCR of Lactococcus lactis subsp. cremoris in milk fermented by a mixed culture. Appl Microb Biotech 66: 414-421

Hanna SE, Connor CJ, Wang HH 2005: Real-time polymerase chain reaction for the food microbiologist: technologies, applications, and limitations. J Food Sci 70: 4953

Irlinger F, Mounier J 2009: Microbial interactions in cheese: implications for cheese quality and safety. Current Opinion in Biotech 20: 142-148

Masoud W, Vogensen FK, Lillevang S, Abu Al-Soud W, Sorensen SJ, Jakobsen M 2012: The fate of indigenous microbiota, starter cultures, Escherichia coli, Listeria innocua and Staphylococcus aureus in Danish raw milk and cheeses determined by pyrosequencing and quantitative real time (qRT)-PCR. Int J Food Microbiol 153: 192-202

Ndoye B, Rasolofo E, LaPointe G, Roy D 2011: A review of the molecular approaches to investigate the diversity and activity of cheese microbiota. Dairy Sci Techn 91: 495-524

Postollec F, Falentin H, Pavan S, Combrisson J, Sohier D 2011: Recent advances in quantitative PCR (qPCR) applications in food microbiology. Food Microb 28: 848-861

Quigley LO, Sullivan O, Beresford TP, Ross RP, Fitzgerald GF, Cotter PD 2011: Molecular approaches to analysing the microbial composition of raw milk and raw milk cheese. Int J Food Microbiol 150: 81-94

Randazzo CL, Caggia C, Neviani E 2009: Application of molecular approaches to study lactic acid bacteria in artisanal cheeses. J Microb Meth 78: 1-9

Singh S, Goswami P, Singh R, Heller KJ 2009: Application of molecular identification tools for Lactobacillus, with a focus on discrimination between closely related species: a review. LWT - Food Sci Techn 42: 448-457

Sohier D, Jamet E, Le Dizes AS, Dizin M, Pavan S, Postollec F, Coton E 2012: Polyphasic approach for quantitative analysis of obligately heterofermentative Lactobacillus species in cheese. Food Microb 31: 271-277

Wouters JTM, Ayad EHE, Hugenholtz J, Smit G 2002: Microbes from raw milk for fermented dairy products. Int Dairy J 12: 91-109 